\title{
Customer Relationship Marketing and Brand Image in Establishing Satisfaction and Loyalty of Advertisers
}

\author{
Hanny Shabrina ${ }^{1} \quad$ Didik J Rachbini $^{2} \quad$ Endi Rekarti $^{3}$ \\ Faculty of Economics and Business, Mercu Buana University \\ West Jakarta, Indonesia
}

\begin{abstract}
This research purpose is to analyse the impact between brand image and CRM (Customer Relationship Marketing) towards the satisfaction of advertisers and the implications towards customer loyalty, with the case study of Metro TV advertiser. The data collection method that was used in this study is the explanatory approach and survey in forms of questionnaire. The measurements are using Likert 1-5 scale. The populations in this research are all the clients or sponsors of Metro TV that have conducted an advertising. Then, there's a random selection for the samples accustomed to Hair et. al' (2010) formula, which wrote the numbers of questions in questionnaire multiplied 5. Thus, the result of samples is 150 people. Data analysis technique that was used in this research was a Structural Equation Modelling (SEM) and processed using Lisrel 8.7. The result of this research shows a positive and significant impact between brand image and CRM towards advertiser satisfaction and the customer loyalty implications in Metro TV study cases.
\end{abstract}

Keywords: CRM (Customer Relationship Marketing), Brand Image, Customer Satisfaction, Customer Loyalty DOI: $10.7176 / \mathrm{EJBM} / 12-29-07$

Publication date:October $31^{\text {st }} 2020$

\section{INTRODUCTION}

Advertisement is a form of communication which is done by a company with a certain amount of payment using a certain media. Russel \& Lane (1990) stated that advertisement is a message that was paid by a sponsor and delivered through couples of mass media communication.

If we watch the advertisement media trends, since more than six decades ago the television media has proved that they're ruling The Indonesia Advertisement World. This is indicated by the presence of national television channel, TVRI. Then followed by the other national television channel which reaches the market target all over the country. Until now, The national television was still the most popular advertisement media. That fact is supported by the data from Nielsen Indonesia which is pictured by the graphic below that shows the value of ADEX (Advertising Expenditure) still placed the highest rank compared to the other traditional media industry such as newspaper, magazine, and radio for the last three years.

Television media is one of the electronic media that has a wide range and has the advantages of the ability to visually demonstrate the use of the product, reaching through the consumers simultaneously through the senses of hearing and sight. The data showed that AC Nielsen placed the television on the top rank as the media that has the highest bidding position for the potential sponsors.

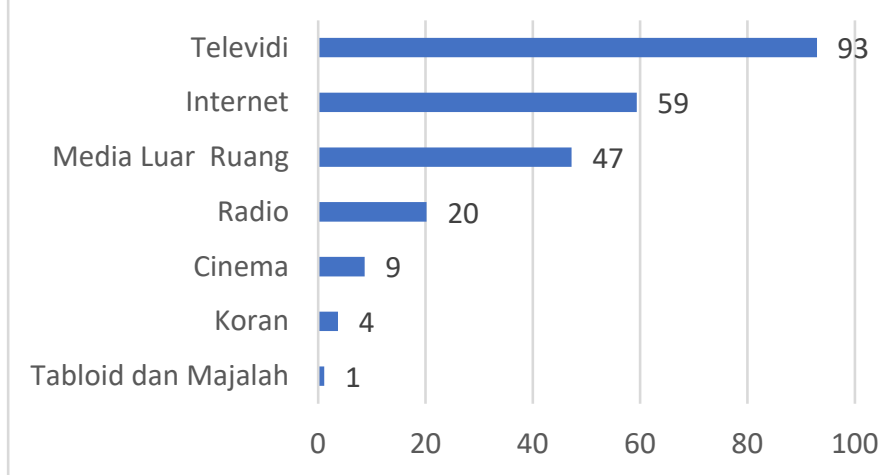

Graphic 1. Media Penetration in Indonesia 2019 Source: Arianna Nielsen/SEC/11 Nielsen Cities 


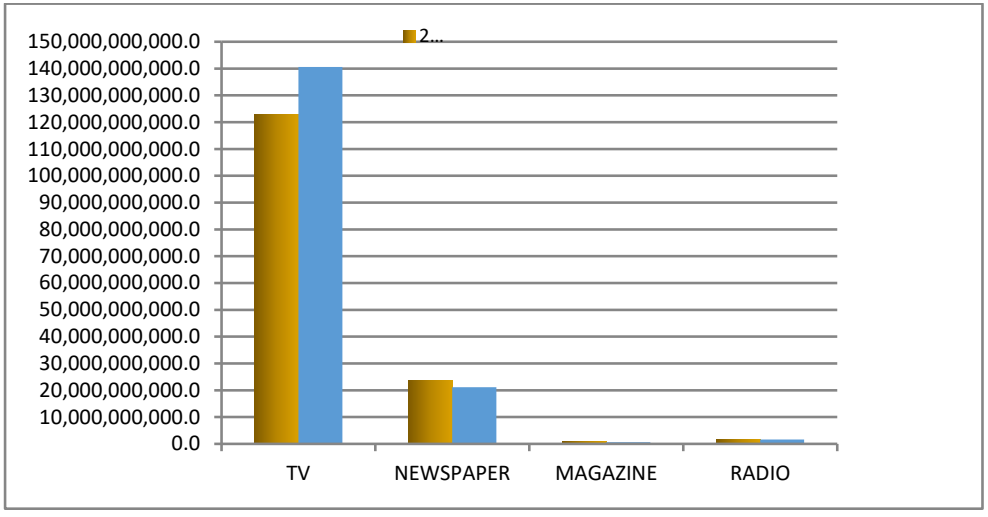

Graphic 2. The Media Advertisement Spending Graphic 2018-2019 Source: Nielsen Media Research Data

Based on the data above, if we view it based on the media type, Television still has the highest contribution. The number of television advertising spending increases from IDR 123 trillion in 2018 to IDR 140 trillion in 2019. Followed by the newspaper advertising spending which decreased by IDR 21 trillion, and the radio advertising spending by IDR 1,6 trillion.

Certainly, the media are competing to be able to survive in the midst of time. From the competition between 15 terrestrial television stations in Indonesia, each has their own competitive edge for sure, which is an ability of a company to gain an economic advantage above the profit that can be achieved by competitors in the same market industry (Michael E Porter, 2008). From each own characters of the television stations to win over the competition, one of the positioning that's done is by having an airing focus in certain content. Seeing the fact that the news is a crucial thing among the people in their daily lives, some television stations are focusing themselves to become a news television channel with programs that reflect news television.

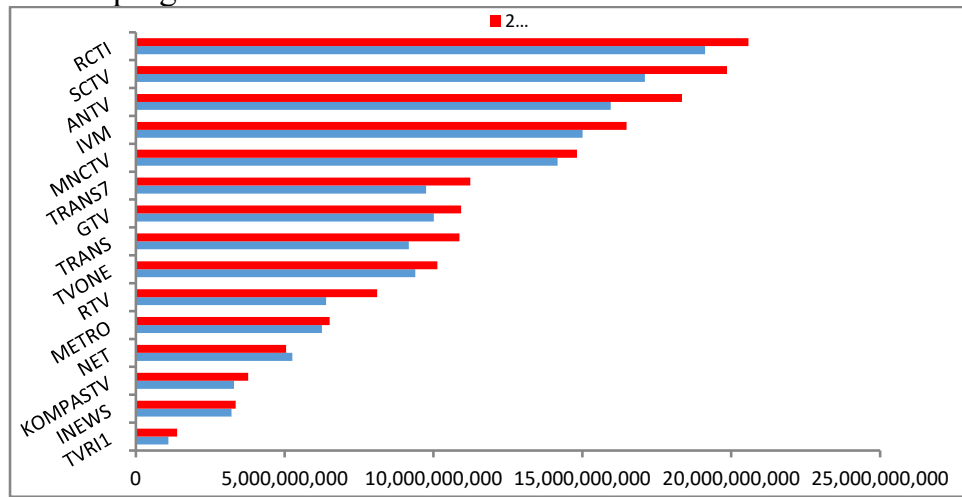

Graphic 3. Advertising Spending/Adex All Channel 2018-2019 Source: Arianna Nielsen 2018-2019

Based on the data above, we can see that RCTI is a private television with the highest advertising spending up to IDR 20,5 Trillion in 2019, and then followed by SCTV as the second private television as the second highest with the value of IDR 19,8 trillion, where based on rating and share, those both television station also succeed in placing three highest position, that is RCTI which placed in the second, and SCTV in the third. For the news television category, the first position is placed by TCOne with an income of IDR 10,1 trillion and followed by Metro TV in the second place with an income of IDR 6,5 trillion. It's also directly proportional to the rating and share rank in news television category which is achieved by TV One in the first place, and Metro TV in the second.

From some of the national television stations in Indonesia, some of those television stations mentioned that their channel is a news channel that is focusing on the news airing and informative stuff to the people. Such as Metro TV, TV One, TVRI, iNews TV, And Kompas TV. The first television station which focused only on news airing with focus on giving news for almost 24 hours in Indonesia is Media Televisi Indonesia or what the people know with Metro TV. Metro TV started airing in 2000, and is still consistent to air the news program until now.

PT. Media Televisi Indonesia or more well-known as Metro TV is the first 24 hours news television in Indonesia which started airing on 25 November 2000. Metro TV is one of the Media Group Company which is owned by Surya Paloh. Metro TV is aimed to spread the news and information all over Indonesia. Other being loaded by news, Metro TV also airing various information programs about the technology advance, common knowledge, art and culture, and the others with the aim to educate the nation.

The Brand Image that's conducted by Metro TV as The Election Channel with Election Programs since 2004 
add the impression that Metro TV is aware of the politic. Meanwhile, the competition between televisions, especially the television that shows more various programs of news and information. Where it is more demanding the program creativity that's supported by the human resource, facility, technology use, and strong finance, also the accurate strategy. Moreover, the presence of others private televisions with the same genre, that is news, such as TV One, Kompas TV, and iNews.

The consequences that must be accepted by the Metro TV as the news television station, where the aired programs won't be as various as the other private television also the awareness of the politics, which is affecting the brand image and the people's perception. However, from a business perspective, Metro TV has managed to become a television station with the highest number of advertisers, beating others 14 television stations.

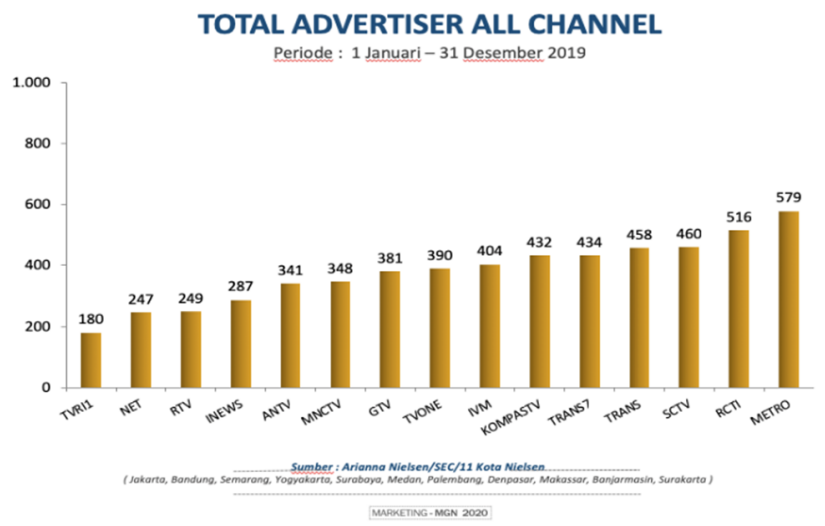

Graphic 4. Total Advertiser all channel period 2019

Source: Adex Nielsen/1 January - 31 December 2019

Based on the description of the background and the datas above, also with observations and the researcher directly analyzing as a practitioner in accordance with the reality on the field, it can be concluded that the high number of advertisers is not directly proportional to the amount of ad spending revenue. There are some factors that cause those television stations to acquire a high amount of advertising spending, that is: rating and share, which is widely used by few companies or agencies with the calculation of cost per rating point (CPRP); the loyalty level of the advertisers which for a commitment to re-advertising. As quoted by Kotler and Keller (2012), which defines loyalty as a deeply held commitment to buy or support a preferred product or service in the future. According to Bothe quoted from Vanessa (2007: 71) provides a definition of customer loyalty as a customer who is satisfied with the company's products or services.

Several previous studies such as Abdul Ghafoor Awan (2014) in Customer Loyalty in Financial Sector: A case study of Commercial Banks in Southern Punjab; Selda Ene \& Betül Ozkaya (2014) in the Study of Corporate Image, Customer Satisfaction and Brand Loyalty in the Context of Retail Stores; As well as Seyed Fathollah Amiri Aghdaie, Razieh Karimi, \& Ali Abasaltian (2015) in Evaluating the Effect of Electronic Banking on Customer Satisfaction and Loyalty states that there is a significant relationship between customer satisfaction and customer loyalty.

As a basis for research, researchers took several previous studies and conducted a pre-survey to determine the independent variable of all account executives as a representation of the sponsor - because the account executive interacts directly with the sponsor. In this pre-survey, the researcher distributed 3 data points that the respondents had to fill in, namely: first, a list of sponsors who were considered loyal in advertising which would later be used as research respondents. Second, whether the loyal sponsor is satisfied with advertising on Metro TV. As a result, $100 \%$ of the respondents provided information that their clients, namely the sponsors, were satisfied advertising on Metro TV. As well as what factors make these sponsors loyal to advertise on Metro TV, here is the following results:

\begin{tabular}{|l|l|l|l|}
\hline No & Factors Affecting Customer Loyalty & Total & Percentage \\
\hline 1 & Brand Image of Metro TV & 11 & $64.7 \%$ \\
2 & Content Program Quality & 5 & $29.4 \%$ \\
3 & Image Quality & 2 & $11.8 \%$ \\
4 & Advertising Price & 3 & $17.6 \%$ \\
5 & Sales Relationship Strategy & 11 & $64.7 \%$ \\
6 & Audience Segmentation & 10 & $58.8 \%$ \\
7 & Others & 2 & $11.8 \%$ \\
\hline
\end{tabular}

From the table and graphic above, can be concluded that the customer loyalty in advertising is motivated by Brand Image factor (64.7\%) and Sales Relationship Strategy (64.7\%) which is classified into Customer Relationship Marketing. 
Based on the description above, this research problem are the following questions:

1. Is there any effect between Metro TV brand image on advertising loyalty?

2. Is there any effect between Metro TV brand image on the advertising satisfaction?

3. Is there any effect between Metro TV Customer Relationship Marketing to the advertising satisfaction?

4. Is there any effect between Metro TV Customer Relationship Marketing to the advertising loyalty?

5. Is there any effect between the advertising satisfaction to the customer loyalty?

\section{THEORITICAL REVIEW}

\section{Brand Image}

Newsom et.al (2010:280) stated that image is an impression of someone, company or institution which is owned by one or a wider community. Buchari (2013:92) said that image is defined as an impression which is acquired in tuned with the knowledge and experience of someone about something. According to Davies et. al. in Vera (2006:35), it is said that image is defined as a view about a company by the external shareholders, especially the customers.

The Brand Asset Valuator (BAV) provides a comparative measure of brand equity for thousands of brands in hundreds of different categories. There are four key components of the pillar of brand equity according to BAV which are used as dimensions and indicators in this research, which is:

a. Differentiation measures the degree to which a brand is seen as different from others.

b. Relevance measures the breadth of a brand's appeal.

c. Esteem measures how well the brand is regarded and respected.

d. Knowledge measures how familiar and intimate consumers are with the brand.

2. CRM (Customer Relationship Marketing)

According to Lovelock and Wright (2007: 118) Relationship Marketing is an activity that aims to develop a longterm relationship with an effective payment between an organization and its customers for the mutual benefit of both parties. The goal of Relationship Marketing is to build long-term, mutually satisfying relationships with key constituents in order to acquire and maintain business (Kotler \& Keller 2012). Based on the definition above, Relationship Marketing is a strategy which is done to build long-term relationships with customers to achieve organizational /company profits.

According to Kotler and Amstrong (2001:304), Shammout et al. (2007:3359), and Chiu et al. (2007:720) there are three approaches that can be developed by the company in maintaining their relationship with the customer, which is:

a. Financial: Financial is the cost savings incurred by customers when they buy products or services from a company.

b. Social: Providing social benefits is more in line with customer needs and desires in a more personal way.

c. Structural ties: Build long-term profitable relationships with customers by providing structural ties which make it easier for customers to transact with the company.

\section{Customer Satisfaction}

Customer Satisfaction is a feeling of pleasure or disappointment of someone that occurs after comparing the performance (results) of the product which have been thought of and the expected performance. Satisfaction is a function from perception or impression of a performance and an expectation. If the performance is below the expectation, then the customer won't be satisfied. But if it's fulfilling the expectation, then the customer would feel satisfied. If the performance is exceeding the expectations, the customer would be very satisfied or happy (Kotler and Keller 2012).

Customer satisfaction depends on the estimated performance of the product in providing value, relative to the buyer's expectations. Kotler (2001:13) stated that the concept of customer expectation and the company performance is if the product performance is much lower than the expectation, the customer won't be satisfied. If the performance is as expected, the customer would be satisfied and if the performance exceeds the expectations, the customer would be happier.

\section{Customer Loyalty}

Oliver as cited by Kotler and Keller (2012) defines loyalty as a deeply held commitment to buy or support back preferred products or services in the future even though the influence of the situation and marketing efforts have the potential to cause customers to switch.

According to Bothe, quoted from Vanessa (2007: 71) provides a definition of customer loyalty as customers who are satisfied with the company's products or services and they become enthusiastic advertisers of word of mouth, loyalty not only to the company's products and services, but also to the entire product portfolio and company services as part of the brand's lifelong loyalty.

According to Laksana (2008:188) there are three dimensions of customer loyalty, which is:

a. Word of mouth communications 
b. Purchase intention

c. Complaining behavior

\section{FRAMEWORK}

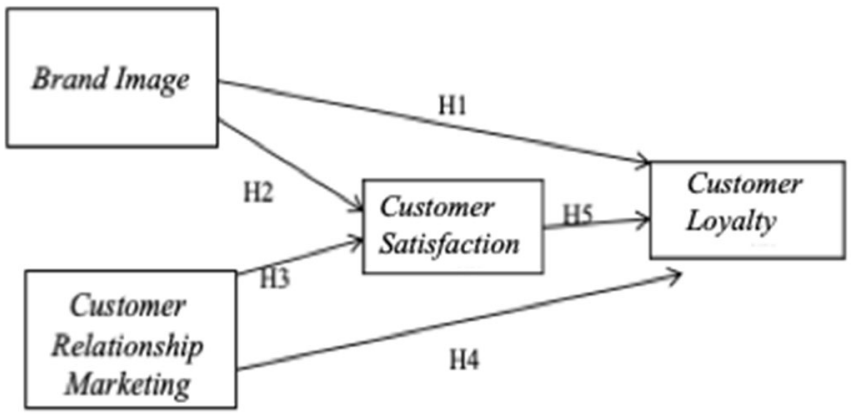

Graphic 5. Research Model

\section{RESEARCH HYPOTHESES}

H1: Brand Image affects Customer Loyalty

H2: Brand Image affects Customer Satisfaction.

H3: Customer Relationship Marketing affects Customer Satisfaction

H4: Customer Relationship Marketing affects Customer Loyalty

H5: Customer Satisfaction affects Customer Loyalty

\section{RESEARCH METHOD}

This research is using a quantitative research method with an explanatory approach through survey. The aim of choosing this explanatory method is because the researcher wants to test the hypothesis of the effect between the independent variables (exogen variable) and the dependent variable (endogene variable). Data and facts from the collected questionnaires will be tested with SEM data analysis technique.

The population of this research is all of the clients of sponsors which has done advertising in Metro TV since 2017-2019 with the minimum 5 times per year advertising, with the amount of 240 advertisers. The amount of sample in this research is decided by using Slovin Formula with the total sample in this research is 150 advertiser.

\section{THE RESEARCH RESULT AND DISCUSSION}

1.1 The Demographic Characteristics of Respondents

The characteristics of 150 respondents which are the clients that had done advertising in Metro TV are:

a. Characteristics of respondents based on the respondents sex consisted of more men, namely 87 men $(58.00 \%)$ than women with amount of 63 person $(42.00 \%)$.

b. Next, from the respondent's working period. 14 respondents $(9.33 \%)$ have a working period of less than 1 year, 15 respondents $(10.00 \%)$ have a working period of 1-2 years, 22 respondents $(14.67 \%)$ have a working period of 2-3 years, 15 respondents (10.00\%) have a working period of 3-4 years, and 84 respondents $(56 \%)$ have a working period of more than 4 years.

c. Based on the respondent's business field, 104 respondents $(69.33 \%)$ have private business fields, 25 respondents (16.67\%) have government business, and 21 respondents $(14.00 \%)$ have other business fields.

Also, based on the period of being client, 7 respondents (4.67\%) has a period of being a client of less than 1 year, 20 respondents $(13.33 \%)$ has a period of being a client between $1-2$ years, 17 respondents $(11.33 \%)$ has a period of being a client between 2-3 years, 38 respondents (25.33\%) has a service period of 3-4 years, and 68 respondents $(45.33 \%)$ has a client period of more than 4 years. 


\subsection{Descriptive Analysis}

Table 1. Variable Brand Image $\left(\mathrm{X}_{1}\right)$

\begin{tabular}{|c|c|c|c|c|c|c|c|c|}
\hline \multirow[b]{2}{*}{$\begin{array}{c}\text { Indicator } \\
\text { Code }\end{array}$} & \multicolumn{5}{|c|}{ Respondent's Answers } & \multirow[b]{2}{*}{ Total } & \multirow[b]{2}{*}{ Mean } & \multirow[b]{2}{*}{$\begin{array}{c}\text { Std } \\
\text { Deviation }\end{array}$} \\
\hline & $\begin{array}{c}\text { Strongly } \\
\text { Disagree }\end{array}$ & Disagree & Neutral & Agree & $\begin{array}{c}\text { Strongly } \\
\text { Agree }\end{array}$ & & & \\
\hline $\mathrm{X} 1.1$ & 2 & 5 & 35 & 75 & 33 & 150 & 3.88 & 0.83 \\
\hline $\mathrm{X} 1.2$ & 2 & 5 & 33 & 80 & 30 & 150 & 3.87 & 0.81 \\
\hline $\mathrm{X} 1.3$ & 1 & 8 & 37 & 75 & 29 & 150 & 3.82 & 0.83 \\
\hline $\mathrm{X} 1.4$ & 2 & 8 & 38 & 78 & 24 & 150 & 3.76 & 0.83 \\
\hline $\mathrm{X} 1.5$ & 2 & 10 & 31 & 79 & 28 & 150 & 3.81 & 0.86 \\
\hline X1.6 & 2 & 6 & 35 & 73 & 34 & 150 & 3.87 & 0.85 \\
\hline Total & 11 & 42 & 209 & 460 & 178 & 900 & & \\
\hline Percentage & $1.22 \%$ & $4.67 \%$ & $23.22 \%$ & $51.11 \%$ & $19.78 \%$ & $100.00 \%$ & 3.84 & 0.69 \\
\hline
\end{tabular}

Based on the table data above, it shows that for the questionnaire statements of Brand Image (X1) variable has six indicators, based on the data spread, there are $1.22 \%$ of respondents stated strongly disagree, $4.67 \%$ respondents stated disagree, $23.22 \%$ respondents stated neutral, $51.11 \%$ stated agree, and $19.78 \%$ respondents stated strongly agree. The mean result of this data is $\mathbf{3 . 8 4}$ which means in interval interpretation is included as the "Agree" category, with the X1.1 indicator having the highest mean of 3.88 which stated that "The program from Metro TV has various information so that it is different from the others new television" is the mostly answered by "Agree" statement in the Brand Image Variable.

Table 2. Variable Customer Relationship Marketing $\left(\mathrm{X}_{2}\right)$

\begin{tabular}{|c|c|c|c|c|c|c|c|c|}
\hline \multirow[b]{2}{*}{$\begin{array}{c}\text { Indicator } \\
\text { Code }\end{array}$} & \multicolumn{5}{|c|}{ Respondent's Answers } & \multirow[b]{2}{*}{ Total } & \multirow[b]{2}{*}{ Mean } & \multirow[b]{2}{*}{$\begin{array}{c}\text { Std } \\
\text { Deviation }\end{array}$} \\
\hline & $\begin{array}{l}\text { Strongly } \\
\text { Disagree }\end{array}$ & Disagree & Neutral & Agree & $\begin{array}{c}\text { Strongly } \\
\text { Agree }\end{array}$ & & & \\
\hline $\mathrm{X} 2.1$ & 3 & 11 & 9 & 54 & 73 & 150 & 4.22 & 0.99 \\
\hline $\mathrm{X} 2.2$ & 2 & 2 & 22 & 37 & 87 & 150 & 4.37 & 0.88 \\
\hline $\mathrm{X} 2.3$ & 3 & 7 & 34 & 50 & 56 & 150 & 3.99 & 0.99 \\
\hline $\mathrm{X} 2.4$ & 4 & 13 & 27 & 60 & 46 & 150 & 3.87 & 1.03 \\
\hline $\mathrm{X} 2.5$ & 3 & 1 & 11 & 99 & 36 & 150 & 4.09 & 0.72 \\
\hline $\mathrm{X} 2.6$ & 4 & 2 & 17 & 77 & 50 & 150 & 4.11 & 0.86 \\
\hline $\mathrm{X} 2.7$ & 2 & 0 & 24 & 57 & 67 & 150 & 4.25 & 0.82 \\
\hline $\mathrm{X} 2.8$ & 4 & 3 & 24 & 52 & 67 & 150 & 4.17 & 0.95 \\
\hline X2.9 & 4 & 2 & 16 & 63 & 65 & 150 & 4.22 & 0.89 \\
\hline $\mathrm{X} 2.10$ & 1 & 3 & 12 & 75 & 59 & 150 & 4.25 & 0.74 \\
\hline $\mathrm{X} 2.11$ & 4 & 0 & 8 & 91 & 47 & 150 & 4.18 & 0.76 \\
\hline $\mathrm{X} 2.12$ & 2 & 4 & 22 & 61 & 61 & 150 & 4.17 & 0.87 \\
\hline $\mathrm{X} 2.13$ & 2 & 8 & 22 & 48 & 70 & 150 & 4.17 & 0.96 \\
\hline $\mathrm{X} 2.14$ & 3 & 4 & 44 & 60 & 39 & 150 & 3.85 & 0.91 \\
\hline $\mathrm{X} 2.15$ & 2 & 5 & 22 & 55 & 66 & 150 & 4.19 & 0.90 \\
\hline $\mathrm{X} 2.16$ & 2 & 2 & 18 & 43 & 85 & 150 & 4.38 & 0.85 \\
\hline Total & 45 & 67 & 332 & 982 & 974 & 2400 & 116 & 071 \\
\hline Percentage & $1.88 \%$ & $2.79 \%$ & $13.83 \%$ & $40.92 \%$ & $40.58 \%$ & $100.00 \%$ & 4.10 & 0.11 \\
\hline
\end{tabular}

Based on the table data above, it shows that for the questionnaire statements on the Customer Relationship Marketing (X2) variable, there are sixteen indicators. Based on the data spread, there are 1.88\% respondents stated strongly disagree, $2.79 \%$ respondents stated disagree, $13.83 \%$ respondents stated neutral, $40,92 \%$ stated agree and $40.85 \%$ respondents stated strongly agree. The mean result in these statements is $\mathbf{4 . 1 6}$ which means in interval interpretation classified into the "Agree" category. The result shows that Customer Relationship Marketing sample range is in the goof category, with the X2.16 indicator has the highest mean of $\mathbf{4 . 3 8}$ which stated "There is a structured mechanism which is provided by Metro TV to interact and accommodate the advertiser needs" is the most answered with "Agree” in Customer Relationship Marketing variable. 
Table 3. Variable Customer Satisfaction (Y)

\begin{tabular}{|c|c|c|c|c|c|c|c|c|}
\hline \multirow{2}{*}{$\begin{array}{l}\text { Indicator } \\
\text { Code }\end{array}$} & \multicolumn{5}{|c|}{ Respondent's Answers } & \multirow[b]{2}{*}{ Total } & \multirow[b]{2}{*}{ Mean } & \multirow{2}{*}{$\begin{array}{c}\text { Std } \\
\text { Deviation }\end{array}$} \\
\hline & $\begin{array}{l}\text { Strongly } \\
\text { Disagree }\end{array}$ & Disagree & Neutral & Agree & $\begin{array}{c}\text { Strongly } \\
\text { Agree }\end{array}$ & & & \\
\hline Y.1 & 2 & 7 & 27 & 75 & 39 & 150 & 3.95 & 0.87 \\
\hline Y.2 & 1 & 5 & 28 & 63 & 53 & 150 & 4.08 & 0.86 \\
\hline Y.3 & 4 & 7 & 29 & 71 & 39 & 150 & 3.89 & 0.94 \\
\hline Y.4 & 3 & 0 & 29 & 86 & 32 & 150 & 3.96 & 0.77 \\
\hline Y.5 & 5 & 14 & 43 & 59 & 29 & 150 & 3.62 & 1.01 \\
\hline Total & 15 & 33 & 156 & 354 & 192 & 750 & \multirow{2}{*}{3.90} & \multirow{2}{*}{0.73} \\
\hline Percentage & $2.00 \%$ & $4.40 \%$ & $20.80 \%$ & $47.20 \%$ & $25.60 \%$ & $100.00 \%$ & & \\
\hline
\end{tabular}

Based on the table data above, it shows that for the questionnaire statements in Customer Satisfaction (Y) variable, there are five indicators. Based on its data spread, there are $2.00 \%$ respondents stated strongly disagre, $4.4 \%$ respondents stated disagree, $20.8 \%$ respondents stated neutral, $47.2 \%$ respondents stated agree and $25.6 \%$ respondents stated strongly agree. The mean result in this statement is $\mathbf{4 . 0 8}$ which means in interval interpretation is classified as "Agree" category. That result showed that the customer satisfaction in its sample range is already in good category, with the Y.2 indicator having the highest mean of 4.08 which stated "I am satisfied with the service and the placement result of advertisement in Metro TV" is the mostly answered by "Agree" in the Customer Satisfaction variable.

Table 4. Variable Customer Loyalty $(\mathrm{Z})$

\begin{tabular}{lcccccccc}
\hline $\begin{array}{c}\text { Indicator } \\
\text { Code }\end{array}$ & $\begin{array}{c}\text { Strongly } \\
\text { Disagree }\end{array}$ & Disagree & Neutral & Agree & $\begin{array}{c}\text { Strongly } \\
\text { Agree }\end{array}$ & Total & Mean & Std Deviation \\
\hline$Z .1$ & 1 & 0 & 20 & 71 & 58 & 150 & 4.23 & 0.73 \\
\hline$Z .2$ & 1 & 1 & 26 & 70 & 52 & 150 & 4.14 & 0.77 \\
\hline$Z .3$ & 1 & 4 & 30 & 62 & 53 & 150 & 4.08 & 0.85 \\
\hline$Z .4$ & 0 & 6 & 30 & 77 & 37 & 150 & 3.97 & 0.78 \\
\hline$Z .5$ & 3 & 10 & 34 & 71 & 32 & 150 & 3.79 & 0.92 \\
\hline$Z .6$ & 1 & 9 & 30 & 74 & 36 & 150 & 3.90 & 0.86 \\
\hline$Z .7$ & 1 & 1 & 27 & 84 & 37 & 150 & 4.03 & 0.72 \\
\hline Total & $\mathbf{8}$ & $\mathbf{3 1}$ & $\mathbf{1 9 7}$ & $\mathbf{5 0 9}$ & $\mathbf{3 0 5}$ & $\mathbf{1 0 5 0}$ & $\mathbf{4 . 0 2}$ & $\mathbf{0 . 6 4}$ \\
\hline Percentage & $\mathbf{0 . 7 6 \%}$ & $\mathbf{2 . 9 5 \%}$ & $\mathbf{1 8 . 7 6 \%}$ & $\mathbf{4 8 . 4 8 \%}$ & $\mathbf{2 9 . 0 5 \%}$ & $\mathbf{1 0 0 . 0 0 \%}$ & \\
\hline
\end{tabular}

Based on the table data above, the data showed that for the questionnaire statements in Customer Loyalty (Z) variable, there are seven indicators. Based on the data spread, there are $0.76 \%$ respondents stated strongly disagree, $2.95 \%$ respondents stated disagree, $18,76 \%$ respondents stated neutral, $48,8 \%$ respondents stated agree, and $29,05 \%$ respondents stated strongly agree. The mean result in this statement is $\mathbf{4 . 2 3}$ which means in interval interpretation is classified into "Agree" category with the Z.1 indicator having the highest indicator of 4.23 which stated that "I am certain that Metro TV won't disappoint and will always give the best even though the offered price is more expensive than the other television" is mostly answered by "Agree" in the Customer Loyalty variable.

1.3 Measurement Model Fit Analysis

The measurement model test in SEM analysis is used to test the indicator validity on each construct. Construct validity tests can be done by viewing the loading factor value of each indicator in construct. In this test the indicators are stated as valid if it has loading factor value $>0.5$ and T-value $>1.96$. Meanwhile the construct reliability test is done by measuring the AVE and CR construct value, construct is stated reliable if the AVE model value is $>0.5$ and CRmode is $>0.7$. Below is the result of the measurement model test of all constructs that will be analyzed in SEM analysis :

Table 5. Brand Image $\left(\mathrm{X}_{1}\right)$ Validity and Reliability Results

\begin{tabular}{|c|c|c|c|c|c|c|}
\hline \multirow{2}{*}{$\begin{array}{l}\text { Indicator } \\
\text { Code }\end{array}$} & \multirow{2}{*}{ SLF } & \multirow{2}{*}{ Standard Errors } & \multirow{2}{*}{$\mathbf{e}^{2}$} & \multicolumn{2}{|c|}{ Reliability } & \multirow{2}{*}{ Information } \\
\hline & & & & $C R \geq 0,70$ & $V E \geq 0,5$ & \\
\hline $\mathrm{X} 1.1$ & 0.71 & 0.19 & 0.04 & \multirow{6}{*}{0.90} & \multirow{6}{*}{0.61} & Valid \\
\hline $\mathrm{X} 1.2$ & 0.69 & 0.19 & 0.04 & & & Valid \\
\hline $\mathrm{X} 1.3$ & 0.55 & 0.39 & 0.15 & & & Valid \\
\hline $\mathrm{X} 1.4$ & 0.67 & 0.24 & 0.06 & & & Valid \\
\hline $\mathrm{X} 1.5$ & 0.74 & 0.19 & 0.04 & & & Valid \\
\hline $\mathrm{X} 1.6$ & 0.55 & 0.43 & 0.18 & & & Valid \\
\hline
\end{tabular}


Table 6. Customer Relationship Marketing $\left(\mathrm{X}_{2}\right)$ Validity and Reliability Results

\begin{tabular}{|c|c|c|c|c|c|c|}
\hline \multirow{2}{*}{ Indicator Code } & \multirow{2}{*}{ SLF } & \multirow{2}{*}{ Standard Errors } & \multirow{2}{*}{$\mathrm{e}^{2}$} & \multicolumn{2}{|c|}{ Reliability } & \multirow{2}{*}{ Information } \\
\hline & & & & $C R \geq 0,70$ & $V E \geq 0,5$ & \\
\hline $\mathrm{X} 2.1$ & 0.59 & 0.63 & 0.40 & \multirow{16}{*}{0.96} & \multirow{16}{*}{0.63} & Valid \\
\hline X2.2 & 0.57 & 0.45 & 0.20 & & & Valid \\
\hline X2.3 & 0.79 & 0.35 & 0.12 & & & Valid \\
\hline $\mathrm{X} 2.4$ & 0.76 & 0.48 & 0.23 & & & Valid \\
\hline X2.5 & 0.55 & 0.22 & 0.05 & & & Valid \\
\hline $\mathrm{X} 2.6$ & 0.69 & 0.26 & 0.07 & & & Valid \\
\hline X2.7 & 0.70 & 0.18 & 0.03 & & & Valid \\
\hline $\mathrm{X} 2.8$ & 0.85 & 0.19 & 0.04 & & & Valid \\
\hline X2.9 & 0.81 & 0.14 & 0.02 & & & Valid \\
\hline $\mathrm{X} 2.10$ & 0.65 & 0.13 & 0.02 & & & Valid \\
\hline $\mathrm{X} 2.11$ & 0.59 & 0.23 & 0.05 & & & Valid \\
\hline $\mathrm{X} 2.12$ & 0.70 & 0.26 & 0.07 & & & Valid \\
\hline $\mathrm{X} 2.13$ & 0.74 & 0.38 & 0.14 & & & Valid \\
\hline $\mathrm{X} 2.14$ & 0.73 & 0.29 & 0.08 & & & Valid \\
\hline $\mathrm{X} 2.15$ & 0.74 & 0.26 & 0.07 & & & Valid \\
\hline $\mathrm{X} 2.16$ & 0.70 & 0.24 & 0.06 & & & Valid \\
\hline
\end{tabular}

Table 7. Customer Satisfaction (Y) Validity and Reliability Results

\begin{tabular}{|c|c|c|c|c|c|c|}
\hline \multirow{2}{*}{$\begin{array}{l}\text { Indicator } \\
\text { Code }\end{array}$} & \multirow{2}{*}{ SLF } & \multirow{2}{*}{ Standard Errors } & \multirow{2}{*}{$\mathbf{e}^{2}$} & \multicolumn{2}{|c|}{ Reliability } & \multirow{2}{*}{ Information } \\
\hline & & & & $\mathrm{CR} \geq 0, \mathbf{0 , 7 0}$ & $V E \geq 0,5$ & \\
\hline Y.1 & 0.63 & 0.35 & 0.12 & \multirow{5}{*}{0.89} & \multirow{5}{*}{0.61} & Valid \\
\hline Y.2 & 0.66 & 0.30 & 0.09 & & & Valid \\
\hline Y.3 & 0.72 & 0.36 & 0.13 & & & Valid \\
\hline Y.4 & 0.76 & 0.01 & 0.00 & & & Valid \\
\hline Y.5 & 0.71 & 0.52 & 0.27 & & & Valid \\
\hline
\end{tabular}

Table 8. Customer Loyalty (Z) Validity and Reliability Results

\begin{tabular}{|c|c|c|c|c|c|c|}
\hline \multirow{2}{*}{ Indicator Code } & \multirow{2}{*}{ SLF } & \multirow{2}{*}{ Standard Errors } & \multirow{2}{*}{$\mathrm{e}^{2}$} & \multicolumn{2}{|c|}{ Reliability } & \multirow{2}{*}{ Information } \\
\hline & & & & $C R \geq 0,70$ & $V E \geq 0,5$ & \\
\hline Z.1 & 0.64 & 0.12 & 0.01 & \multirow{7}{*}{0.94} & \multirow{7}{*}{0.69} & Valid \\
\hline Z.2 & 0.61 & 0.22 & 0.05 & & & Valid \\
\hline Z.3 & 0.73 & 0.19 & 0.04 & & & Valid \\
\hline Z.4 & 0.67 & 0.16 & 0.03 & & & Valid \\
\hline Z.5 & 0.74 & 0.31 & 0.10 & & & Valid \\
\hline Z.6 & 0.73 & 0.20 & 0.04 & & & Valid \\
\hline Z.7 & 0.55 & 0.21 & 0.04 & & & Valid \\
\hline
\end{tabular}

1.4 Structural Model Fit Analysis

1.4.1 Overall Model Variable

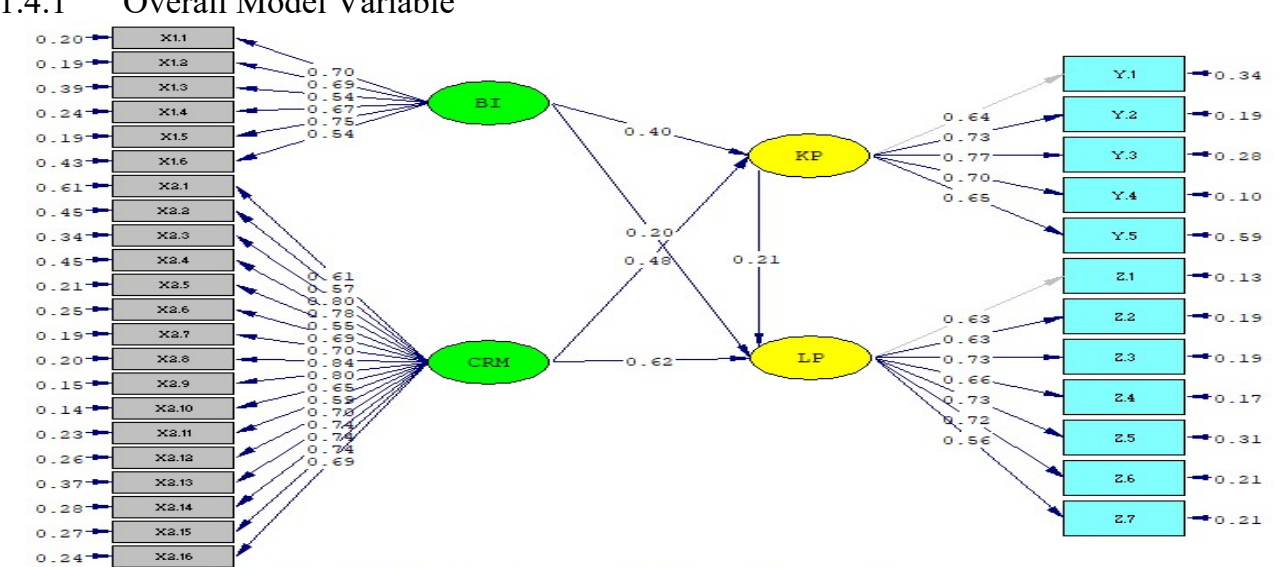

Source: Analysis Result using Lisrel 9.2 
1.4.2 Goodness of Fit Full Model Test Result

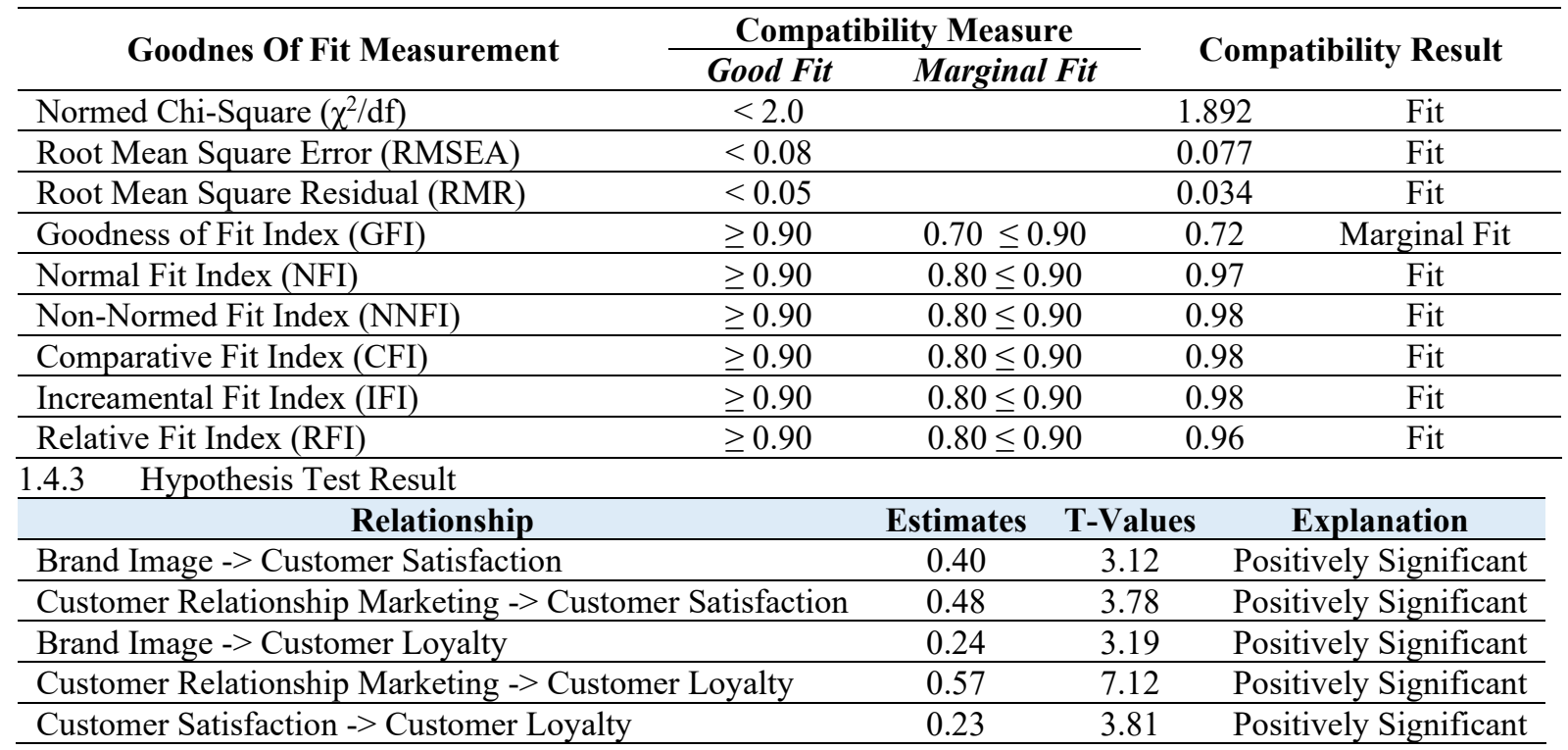

\section{CONCLUTION}

Based on the stages that the researchers have done, starting from collecting to processing data to answer the research questions, this study empirically get the following conclusions:

1. The Brand Image Variable has a positive effect and is significant on Customer Loyalty. It meant that the better the company's image that's been conducted or owned by Metro TV, the more advertiser loyalty will increase

2. Brand Image Variable has a positive effect and is significant on Customer Satisfaction. It means that the more a company's image that's been conducted or owned by Metro TV, the more it will affect the increase of client's satisfaction in advertising in Metro TV.

3. The Customer Relationship Marketing Variable which is one of the Metro TV marketing strategies has a positive effect and is significant with a pretty high percentage in this research on customer satisfaction, which is the client or the advertiser on Metro TV.

1. The Customer Relationship Marketing Variable which is one of Metro TV marketing strategies has a positive effect and significant on the high loyalty of advertiser.

2. The Customer Satisfaction Variable, which is the client or the advertiser in Metro TV has a significant positive effect on the customer loyalty. It means that the higher the advertiser satisfaction, it will affect the high loyalty of the advertiser too.

\section{REFERENCES}

Alma, Buchari. (2013). "Manajemen Pemasaran dan Pemasaran Jasa”. Cetakan Kesepuluh. Bandung : Alfabeta. Bothe, Keki. R. (1996). "Beyond customer satisfaction to customer loyalty: the key to greater profitability". New York: American Management Association (AMA) membership publication divition.

Chiu, Hung-Chang. et al. (2007). "Building Customer Relationship : A Comparison Accros Multiple Service Encounters". Dalam Advances in Consumer Research Volume 34. Taiwan: National Chung Hsing University.

Christoper Lovelock \& Lauren K Wright. (2007). "Manajemen Pemasaran Jasa", PT. Indeks, Indonesia

Davies, G., Chun, R., da Silva, R., and Roper, S. (2001). "The personification metaphor as a measurement approach for corporate reputation", Corporate Reputation Review, 4(2), 113-127.

Kotler, P. (2001). "A framework for marketing management". Upper Saddle River, NJ: Prentice-Hall.

Kotler, Philip. dan Kevin Lane Keller. (2012). “Manajemen Pemasaran”. Jilid 1 Edisi 12. Terjemahan BobSabran. Erlangga. Jakarta.

Laksana, Fajar. (2008). "Manajemen Pemasaran". Yogyakarta: Penerbit Graha Ilmu.

Newsom et.al (2010). "Public Relations Writing; Form \& Style)". Cengage Learning, Inc

Porter (2008). "The Five Competitive Forces That Shape Strategy". Harvard business review

Russell \& Lane (1990). "Kleppner's Advertising Procedure" Prentice Hall. Pennsylvania State University

Shammout, A., Polonsky, M., \& Edwardson, V. (2007). "Relational Bonds and Loyalty: The Bonds that Tie", (January 2012). Retrieved from http://anzmac.org/conference_archive/2007/pape rs/AShammout_1.pdf

Vanessa F, Gaffar. (2007). "CRM dan MPR Hotel (Customer Relationship Management and Marketing Public Relations)". Bandung: Penerbit Alfabeta. 